reconvenes his inquest and a formal verdict is returned in accordance with that of the criminal court. It is this verdict that the Registrar General includes in his own statistics. Thus, those who dispute the Registrar General's statistics for death due to "homicide and injury purposely inflicted by other persons" quarrel with the judiciary.

Dr. Franklin states that his figure of 700 infant deaths due to "baby battering" is a projection based primarily on studies in Preston by Dr. M. H. Hall. ${ }^{3}$ Dr. Hall recorded five such deaths between 1970 and 1972. He has stated (personal communication): "To attempt to project my small series into national incidence would be the height of statistical folly." -I am, etc.,

Grendon, Warwickshire

KENNETH T. FARN

1 Cavenagh, W. E., Fustice of the Peace, 1974.

2 Franklin, A. W., The Times, 9 June 1975.

\section{Reticulum Cell not a Haematopoietic Stem Cell}

SIR,-In their article on myeloproliferative disorders in the series on blood and neoplastic diseases (16 November 1974, p. 399) Drs. S. M. Lewis and L. Szur state that the "reticulum cell is thought to be the haematopoietic precursor cell from which originate the erythrocyte, granulocytic leucocyte, and megakaryocyte." In a diagram they illustrate this view and suggest the relationship with myeloproliferative disorders. There is no experimental evidence, however, that the reticulum cell can be the haematopoietic stem cell. Ontogenetic studies showed that the haematopoietic stem cell originates in the yolk sac, is next present in the fetal liver. ${ }^{2}$ and finally in the bone marrow. To the best of present knowledge the pluripotent haematopoietic stem cell in postnatal life has the morphology of a small round cell like a small lymphocyte but quite distinct from that of the reticulum cell. ${ }^{3}$ The reticulum cell, on the other hand, is a large cell with specific morphological features and forms reticulin fibres. ${ }^{4-6}$

In our view it is more appropriate to make a distinction between cells deriving from the haematopoietic stem cell and those from mesenchymal origin (see fig.). ${ }^{7}$ Such a distinction based on morphological, cytochemical, functional, and kinetic characteristics offers ample opportunity for the classification of myeloproliferative and other neoplastic diseases. ${ }^{7}$-We are, etc.,

R. VAN FURTH J. W. M. VAN DER MEER

Academish-Zickenhuis,

Leiden, Netherlands

Moore, M. A. S., and Metcalf, D., British fournal of Haematology 1970, 18, 279.

2 Cline, M. J., and Moore, M. A. S., Blood, 1972, 39,842 .

3 Bekkum, van D. W., et al., Blood, 1971, 38, 547. munity, Infection and Pathology, p. 111. Oxford, Blackwell, 1975.

5 Carr, I., in Mononuclear Phagocytes in Immunity, well, 1975.

6 Hoefsmit, E. Ch. M., in Mononuclear Phagocytes in Immunity, Infection and Pathology, p. 129.

Furth, van R., Langevoort, H. L., and Schaberg, A., in Mononuclear Phagocytes in Immunity. Infection 1975 .

\section{Pemphigus Induced by D-Penicillamine}

SIR,-We have observed six cases of bullous cutaneous eruptions with features of pemphigus in patients who were (or had been recently) receiving D-penicillamine (DP) for seropositive rheumatoid arthritis. The clinical aspect of the eruption was in one case typical mucocutaneous pemphigus vulgaris and in the remaining five cases a purely cutaneous bullous disease, which presented three times as pemphigus seborrheicus and once as dermatitis herpetiformis. The diagnosis of pemphigus was based in all cases on: (1) the Tzanck cell test; (2) histological demonstration of acantholysis; and (3) circulating antibodies to intercellular substance, the titre of which was rather low except in one case in which it reached 1/1600.

The bullous disease developed during DP treatment in five cases (in one on resuming treatment after an interval). In the sixth patient the pemphigus started after DP had been withdrawn for several months owing to a previous non-specific bullous rash. (Another case, seen in collaboration with Dr. C. Grupper, showed a similar delayed

\section{DIFFERENTIATION AND LOCALIZATION OF CELLS DERIVED FROM} THE HAEMOPOIETIC STEM CELL AND MESENCHYMAL CELLS

\begin{tabular}{|c|c|c|}
\hline Bone Marrow & Blood & $\begin{array}{l}\text { Lymphatic orgons } \\
\text { and } \\
\text { Connective tissue }\end{array}$ \\
\hline
\end{tabular}

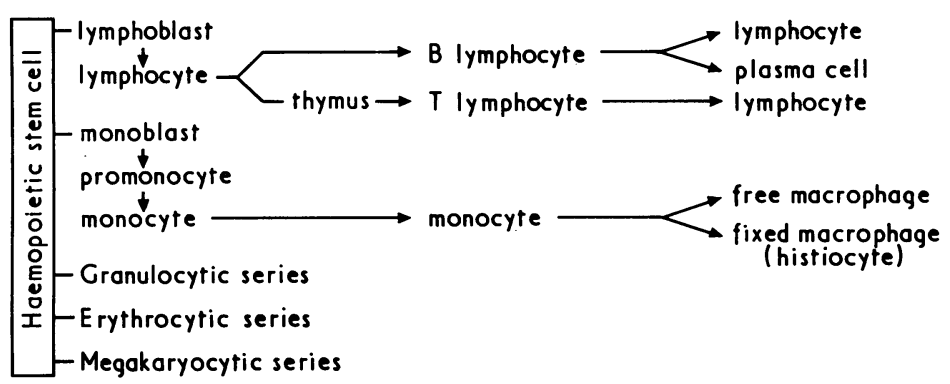

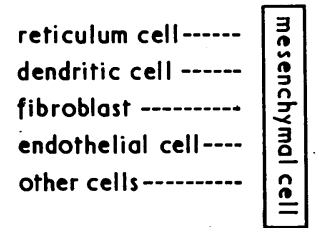

onset.) The evolution of the disease followed two patterns: a benign one, rapidly stopped by moderate doses of corticosteroids, and a classical course, sometimes very difficult to control.

Before these six patients were seen at our clinic a previous case had been reported in a patient under treatment for Wilson's disease. ${ }^{1}$ Since our first reports of this condition $^{23}$ and our further observations we have received verbal communication of three more French cases, making a total of 10 known cases of DP-induced pemphigus.

Two kinds of DP produced by three pharmaceutical firms share the responsibility of inducing the 10 cases of pemphigus: French extractive DP (Hôpitaux de Paris): Knoll's extractive DP, and Bayer's synthesized DP.

The pathogenic implications of these data may afford a new approach to research on the aetiology of pemphigus.-We are, etc.,

J. HEWITT M. BENVENISTE M. LESSANA-LEIBOWITCH Clinique Tarnier,
Paris

1 Degos, R., et al., Bulletin de la Société Française de Dermatologie et de Syphiligraphie, 1969, 76, 751 .

2 Hewitt, J., et al., Annales de Médecine Interne, Benveniste, M., Thèse, Paris, 1972.

\section{Sequelae of Delayed Spontaneous Respiration in Breech Infants}

SIR,-The current controversy about vaginal versus caesarean delivery for breech infants ${ }^{1}$ has led me to follow up infants from a series of 106 vaginal breech deliveries without death from tentorial tear to see whether infants who were kept alive by prompt intubation and prolonged positive pressure respiration (P.P.R.) developed gross longterm sequelae. The three who failed to breathe spontaneously within $20 \mathrm{~min}$ have all been traced and only one is grossly handicapped, being spastic and slightly mentally retarded at 3 years. This child was born at 40 weeks gestation (birth weight $3.7 \mathrm{~kg}$ ) after concealed accidental haemorrhage, was shocked at birth, and was treated with P.P.R. for $30 \mathrm{~min}$. The second was born at 37 weeks (birth weight $2.35 \mathrm{~kg}$ ) with a true knot in the cord and without a palpable apex beat. $\mathrm{He}$ was treated with cardiac massage and P.P.R. for $60 \mathrm{~min}$. At 12 years he is of average intelligence with no sign of spasticity. The third infant was born at 34 weeks (birth weight $2.3 \mathrm{~kg}$ ) with a prolapsed cord and received P.P.R. for $40 \mathrm{~min}$. He had numerous childhood illnesses and was slow in developing speech and learning to read, but at 12 years he has overcome these difficulties, is tall and well built, and is "coltish" in his movements without being too clumsy. In the first case forceps were applied to the after-coming head; in the other two the MauriceauSmellie-Weit technique was used for delivery.

All four infants who failed to breathe spontaneously within $20 \mathrm{~min}$ after toxic accidental haemorrhage in Neligan's series, ${ }^{2}$ however delivered, developed cerebral palsy. (Our case, taken with his, leads us to the conclusion that one should desist from P.P.R. after $20 \mathrm{~min}$ in any infant after concealed accidental haemorrhage.) 
It seems clear that the only spastic infant in our series would have been equally likely to be handicapped had it been delivered by caesarean section and, in our hands, prolonged resuscitation did not keep alive spastics caused by the mode of delivery, so depressing our perinatal loss rate. I thank Mr. E. O. Williams and Mr. S. S. F. Pooley for permission to follow up the patients referred to, who were under their care.-I am, etc.,

\section{F. ANN Musson}

Topsham, Devon

1 Meeting of the Royal Society of Medicine, Obstetrics and Gynaecology Section, 30 May 2 Neligan, G., et al., The Formative Years; Birth, Family and Development in Newcastle upon Tyne. Nuffield Provincial Hospitals
London, Oxford University Press, 1974.

\section{Adrenal Tumours and Hypertension}

SIR,-We were interested to read the comments of Dr. V. Tchertkoff and colleagues (24 May, p. 444), though we have reservations in accepting their statement that adrenocortical nodules "have no relation whatsoever to hypertension." Others have described a higher incidence of such lesions in hypertensive patients compared with normotensives coming to necropsy..$^{1-4}$

All the patients in our series (18 January, p. 135) had hypertension with aldosterone excess. The pathological findings were as we reported. However, we did not conclude that the adrenocortical nodules in these patients had an aetiological role in either the hypertension or the aldosterone excess. Indeed, as previously reported, 5 nodules were not identified in all patients, even among those in whom no tumour was found.-We are, etc.,

\section{J. B. FERRISS \\ J. J. BROWN \\ D. L. DAVI}

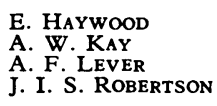

Western

St. Mary's Hospital,

London $\mathbb{W} .2$

1 Dobbie, J. W., Fournal of Pathology, 1969, 99, 1. Symington, T., Functional Pathology of the
Human Adrenal Gland. Edinburgh, Livingstone, Human.

3 Neville, A. M., Mackay, A. M., Clinics in Endocrinology and Metabolism, 1972, 1, 361.

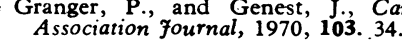

5 Ferriss, J. B., et al., Lancet, 1970, 2, 995.

\section{Orbital Bruits in Patients on Maintenance} Haemodialysis

SIR,-Referring to the investigation by $\mathrm{Mr}$. S. R. Lancer and others (31 May, p. 481) of orbital bruits in patients on maintenance haemodialysis, we want to report an investigation we made of this subject.

We used the same method as Mr. Lancer ard his colleagues. Two groups of patients were studied: 11 children on maintenance haemodialysis with an A.V. fistula and six children after renal transplantation with a still-functioning fistula. Their ages ranged from 5 to 17 years. All had a proximal and large A.V. fistula consisting of a saphenous loop inserted between the brachial artery and the cephalic vein. Seven of the patients on maintenance haemodialysis had an orbital bruit. After occlusion of the fistula the bruit disappeared in one patient but appeared in two others without bruit with open fistula. The presence of the bruit was clearly related to the level of the packed cell volume. None of the patients with a functioning kidney transplant had an orbital bruit despite the presence of a large A.V. fistula. All patients had a packed cell volume greater than $35 \%$.

We can endorse the importance of anaemia in relation to the appearance of an orbital bruit. The influence of the A.V. fistula is of less importance.-We are, etc.,

R. N. SUKHAI

R. A. DONCKERWOLCKE

University Children's Hospital,

Utrecht. Netherlands

\section{An Easy Death-An Uneasy Argument}

SIR,-Dr. M. A. Simpson's letter (19 July, p. 155) does indeed clarify the position in that he tacitly admits that good terminal care and active euthanasia are becoming synonymous. It only needs a breakthrough in consensus thinking, like that which made the Abortion Act of 1967 possible, to introduce "voluntary dying" as a respectable and accepted alternative to "natural dying" in circumstances defined by law. I introduce the subject of abortion because both abortion and euthanasia are expressions of active interference with natural processes to the denial of unwanted life-in the one case not yet born, in the other not yet concluded.

The frequency of suicide in dying patients is open to further study. One wonders how accurate are statistics in this connexion, since any compassionate doctor would record the killing disease as "cause of death" under such circumstances, not that the patient had stopped eating or breathing of his own accord. Other, more obvious methods would be beyond the strength of many terminal patients, though cases do occur of poor, distracted sufferers who have embraced death by more obvious means.

The diseases Dr. Simpson quotes are often associated with euphoria. For many people an organic disease is a relief from the unendurable tensions of life. It is when the disease has reached its terminal stage that the protracted business of dying has to be suffered to the advantage of none but simply out of deference to outworn conventions of the sanctity of life.-I am, etc.

\section{S. L. HENDERSON SMITH}

Huddersfield

\section{Increased Serum Iron in Acute Leukaemia}

SIR,-We should like to correct Dr. F. Rosner's misconception (12 July, p. 100) regarding ferritin in acute leukaemia. Our paper (1 February, p. 245) was concerned only with serum ferritin protein concentrations. Ferritin is indeed an iron-containing protein and its concentration in the serum correlates well with total body iron stores in normal subjects. In leukaemic patients this relationship does not appear to exist, and in fact we found no correlation between serum ferritin and serum iron concentration. ${ }^{1}$

In patients with acute myeloblastic leukaemia a gross rise in both serum and white cell ferritin concentrations was ob- served but the white cell ferritin appeared to be mainly apoprotein' ${ }^{2}$ - that is, ferritin with very little iron in it. Furthermore, our preliminary studies on serum ferritin, at least in states of iron overload, show that it also is mainly apoferritin. ${ }^{2}$

We think it is important to appreciate the difference between serum iron (that is, transferrin-bound iron) and serum ferritin, especially in states such as acute leukaemia where the serum ferritin concentration probably bears little relationship to the iron stores of the patient.-We are, etc.,

D. H. PARRY M. WORWOOD A. JACOBS

University Hospital of Wales,
Cardiff

1 Worwod $M$. British fournal of HaemaWorwood, M., et al.,
tology, 1974, 28, 27. Worwood, M., et al., Clinical Science and
Molecular Medicine, $1975,48,441$.

Infection after Insertion of I.U.D.

SIR,-The report by Dr. M. de Swiet and others (12 July, p. 76) of bacterial endocarditis diagnosed six weeks after the insertion of an intrauterine contraceptive device (I.U.D.) suggests that a causal relationship might exist and a recommendation is made regarding prophylactic chemotherapy. The bacteriological assessment of the case is admittedly incomplete and I suggest that the relationship was a causal one.

From 1964 I established a clinic at the Birmingham and Midland Hospital for Women where I.U.D.s were fitted to over 2000 patients whose immediate follow-up was excellent, though it lapsed subsequently. It has been a matter of surprise that clinical evidence of infection has been so trivial after such a comparatively unsterile procedure. No serious inflammatory complication that could reasonably be attributed to the I.U.D. has been noted. An exacerbation of pre-existing venereal infection was diagnosed in two patients. One woman developed gastroenteritis within 12 hours of fitting and the device was removed but refitted uneventfully afterwards. One patient evacuated a pyometra two years after fitting, but her uterine cavity was sterile and another device was fitted at her request. One patient was operated on for acute pelvic peritonitis two years after fitting, when the device was removed and bacterial swabs from it and from the pelvic peritoneum both showed haemolytic streptococci. Subsequent bacteriology, however, proved them to be of different types.

The successful use of the I.U.D. must depend largely on the astonishing resistance to infection of the endometrial cavity in the absence of pregnancy. I would like to emphasize my personal opinion, however, that an I.U.D. should be removed whenever possible as soon as any pregnancy should be diagnosed.-I am, etc.,

WILFRID MILLS

Birmingham

\section{Metastatic Carcinoma Causing Haematemesis}

SIR,-We were very interested in the description by Dr. E. Edward and Mr. G. Royle of a case of haematemesis due to gastric metastases from bronchial carcinoma (14 June, p. 598). We wish to report a similar case recently presenting with profound anaemia and widespread gastrointestinal 